\title{
Plasma Concentration of Immunoglobulin Classes and Subclasses in Children with Autism in the Republic of Macedonia: Retrospective Study
}

\author{
Vladimir Trajkovski, Ljubomir Ajdinski, Mirko Spiroski ${ }^{1}$ \\ Institute of Special Education and Rehabilitation, Faculty of Philosophy; and ${ }^{1}$ Institute of Immunobiology and \\ Human Genetics, Medical Faculty, Skopje, Republic of Macedonia
}

Aim. To examine plasma concentration of $\lg \mathrm{A}$, $\lg M$, $\lg G$ classes, and $\lg \mathrm{G} 1$, $\lg \mathrm{g} 2$, $\lg \mathrm{G} 3$, and $\lg \mathrm{G} 4$ subclasses in children with autism.

Methods. Infantile autism was diagnosed by the Diagnostic and Statistical Manual for Mental Disorders (DSM)-IV and the International Classification of Diseases (ICD)-10 criteria. Plasma samples were collected from 35 autistic subjects, and their 21 siblings (biological brothers and sisters) who served as healthy controls. Plasma samples were separated by centrifugation and stored at $-20^{\circ} \mathrm{C}$ until the determination. Plasma immunoglobulin classes (IgM, IgA, $\operatorname{lgG}$ ) and subclasses (lgG1, IgG2, IgG3, IgG4) were determined using a nephelometer.

Results. Plasma concentrations (mean \pm standard deviation) of $\lg M$ and $\operatorname{lgG}$ in autistic children $(1.36 \pm 0.31 \mathrm{~g} / \mathrm{L}$ and $13.14 \pm 1.27 \mathrm{~g} / \mathrm{L}$, respectively) were significantly higher $(\mathrm{p}=0.031$ and $\mathrm{p}=0.023$, respectively) in comparison with their healthy brothers or sisters $(1.20 \pm 0.15 \mathrm{~g} / \mathrm{L}$ and $12.39 \pm 0.96 \mathrm{~g} / \mathrm{L}$, respectively). Children with autism had significantly higher plasma concentrations of IgG4 $(\mathrm{p}<0.001)$ compared to their siblings (healthy brothers or sisters). Plasma concentration of $\lg A$, $\operatorname{lgG} 1$, IgG2, and $\operatorname{lgG} 3$ were similar in autistic children and their healthy brothers or sisters. Increased plasma concentration of $\operatorname{lgG} 1$ was found $(p=0.027)$ in autistic males $(8.06 \pm 2.40)$, as compared with their healthy brothers (5.24 $\pm 4.13 \mathrm{~g} / \mathrm{L})$. Plasma concentrations of $\operatorname{lgG}(14.28 \pm 3.66 \mathrm{~g} / \mathrm{L})$, and $\operatorname{lgG} 1(9.41 \pm 2.20 \mathrm{~g} / \mathrm{L})$ in autistic females were increased $(p=0.012$ and $p=0.021$, respectively) in comparison with $\operatorname{lgG}(11.07 \pm 2.07)$ and $\operatorname{lgG} 1(6.37 \pm 3.38 \mathrm{~g} / \mathrm{L})$ in their healthy sisters.

Conclusion. Children with autism have increased plasma concentration of immunoglobulines. Increased immunoglobulines in children with autism could be a result of impaired development of the immune system, and/or genetic factors connected with defense mechanism in these children.

Key words: autistic disorder; immunoglobulin isotypes; Macedonia (Republic)

Autism is a severe neurodevelopmental disorder characterized by a triad of impairments in reciprocal social interaction, verbal and nonverbal communication, and a pattern of repetitive stereotyped activities, behaviors, and interests (1).

A number of factors have been implicated in the pathogenesis of autism including genetic (2), environmental (3), and immunological (4). Some evidence suggests that the immune system plays an important role in the pathogenesis of autism. These include changes in lymphocyte subsets (5), alteration in serum concentration of immunoglobulin classes and subclasses $(6,7)$ and cytokine production (8), presence of autoantibodies to neural antigens (9), increased frequency of the C4b null allele (10), and linkage to some immune response genes (11).

Abnormal immunoglobulins (low IgA, increased $\operatorname{lgE}$ ), decreased natural killer cells and other T-cell abnormalities may reflect the "disregulation" of the im- mune system in persons with autism (12). The alteration in the immune system may also occur in parallel to changes in the developing central nervous system (CNS), and both may have the same etiologies that underlie autism $(9,13-15)$. Therefore the immune abnormalities would appear to be causative (16).

The aim of the study was to examine the plasma concentration of immunoglobulin classes and subclasses as indicators of dysregulated immune system, as well as gender differences in children with autism.

\section{Subjects and Methods}

Subjects

The investigation was performed retrospectively in 50 persons with autism registered in the social institutions of the Republic of Macedonia from April, 2000 untill April 2002 year. Infantile autism was diagnosed by the Diagnostic and Statistical Manual for Mental Disorders (DSM)-IV (1) and the International Classification of Diseases (ICD)-10 (17) criteria. Complete information was provided for only 39 of the total number of persons with au- 
tism. Blood for immunogenetic investigations was taken from 35 persons with autism ( 24 boys and 11 girls), as well as from 21 their siblings ( 7 boys, and 14 girls) after obtaining their informed consent (4 persons did not accept to participate in the investigation). Ten milliliters of venous blood was drawn from each donor by standard venipuncture, using vacutainer with EDTA after parental consent. At the time of blood drawing, none of autistic children were receiving any prescription medication or antipsychotic drug.

Immunoglobulin Measurement

Plasma samples were separated by centrifugation, and stored at $-20^{\circ} \mathrm{C}$ until the determination. Serum immunoglobulin classes (IgA, IgG, IgM, and IgE) and subclasses (IgG1, IgG2, IgG3, and IgG4) were determined immunonephelometricallly by an automated Nephelometer Analyzer BN-100 (Dade-Behring, Vienna, Austria).

\section{Statistical Analysis}

Data were analyzed using standard statistical program Statgraphics Plus for Windows version 2.1 (Microsoft Corp., Redmond, WA, USA). The probability level ( $p$-value) was evaluated by the Student's $t$ test. The results are presented as the arithmetic mean \pm standard deviation (SD). $P$ values of 0.05 or less were considered significant.

\section{Results}

Age and plasma concentration of immunoglobulin classes and subclasses in children with autism and their siblings (their healthy brothers or sisters) are presented in Table 1 and 2.

Children with autism were younger than their healthy brothers or sisters $(10.14 \pm 5.81$ vs $13.14 \pm$ 6.45 years, $p=0.078$ ). Autistic males were significantly younger that their healthy brothers $(9.88 \pm 5.75$ vs $14.14 \pm 3.44$ years, $p=0.031$ ) but the age differences between the autistic females and their healthy sisters were not significant (Tables 1 and 2).

Plasma concentration of IgM in autistic chlidren was significantly higher $(p=0.031)$ in comparison

Table 1. Age and plasma concentration of immunoglobulin classes and subclasses (mean \pm standard deviation) in children with autism and their healthy brothers or sisters

\begin{tabular}{lrrr}
\hline & $\begin{array}{c}\text { Autistic children } \\
(\mathrm{n}=35)\end{array}$ & $\begin{array}{l}\text { Healthy brothers } \\
\text { or sisters }(\mathrm{n}=21)\end{array}$ & \multicolumn{1}{c}{$\mathrm{p}^{*}$} \\
\hline Parameters & $10.10 \pm 5.8$ & $13.10 \pm 6.5$ & 0.078 \\
Age (year) & & & \\
Immunoglobulins (g/L): & $1.63 \pm 0.33$ & $1.52 \pm 0.30$ & 0.217 \\
IgA & $1.36 \pm 0.31$ & $1.20 \pm 0.15$ & 0.031 \\
IgM & $13.14 \pm 1.27$ & $12.39 \pm 0.96$ & 0.023 \\
IgG & $8.45 \pm 0.82$ & $8.09 \pm 0.60$ & 0.086 \\
IgG1 & $2.44 \pm 0.38$ & $2.34 \pm 0.52$ & 0.441 \\
IgG2 & $0.46 \pm 0.07$ & $0.45 \pm 0.09$ & 0.644 \\
IgG3 & $0.69 \pm 0.14$ & $0.45 \pm 0.14$ & $<0.001$ \\
IgG4 & & &
\end{tabular}

*Student's t-test. with their healthy brothers or sisters $(1.36 \pm 0.31$ and $1.20 \pm 0.15 \mathrm{~g} / \mathrm{L}$, respectively). Plasma concentration of total IgG in autistic children was significantly higher $(p=0.023)$ in comparison with their siblings (13.14 \pm 1.27 and $12.39 \pm 0.96 \mathrm{~g} / \mathrm{L}$, respectively). The mean value of plasma concentration for IgG4 in autistic group was $0.69 \pm 0.14 \mathrm{~g} / \mathrm{L}$, and in control group $0.45 \pm 0.14 \mathrm{~g} / \mathrm{L}$, and was significantly increased in autistic patients $(p<0.001)$. Plasma concentrations of immunoglobulin classes and subclasses were similar in autistic children and their healthy brothers or sisters for IgA, IgG1, IgG2, and IgG3 (Table 1).

Significantly higher $\operatorname{lgG} 1$ concentration $(p=0.027)$ was found in autistic males $(8.06 \pm 2.40 \mathrm{~g} / \mathrm{L})$, as compared with their healthy brothers $(5.24 \pm 4.13 \mathrm{~g} / \mathrm{L})$. Plasma concentrations of $\operatorname{lgG}(14.28 \pm 3.66 \mathrm{~g} / \mathrm{L})$, and IgG1 $(9.41 \pm 2.20 \mathrm{~g} / \mathrm{L})$ in autistic females were significantly increased $(p=0.012$ and $p=0.021$, respectively) in comparison with $\operatorname{lgG}(11.07 \pm 2.07 \mathrm{~g} / \mathrm{L})$, and $\operatorname{lgG} 1(6.37 \pm 3.38 \mathrm{~g} / \mathrm{L})$ in their healthy sisters (Table 2$)$.

\section{Discussion}

Our study showed that children with autism had significantly increased values of $\lg M$, IgG, and IgG4 compared with their healthy siblings. This could be a consequence of enhanced autoimmunity and/or allergy in persons with autism. Autistic males compared with their healthy brothers and autistic females compared with their healthy sisters, had increased plasma concentration of IgG1. In addition, autistic females had significantly higher plasma concentration of total IgG in comparison with their healthy sisters. These results differ from the cumulative data for all the children with autism, independent of the gender.

Studies of immunoglobulins or titers of antibodies in autistic patients have yielded contradictory results. Some investigators found no abnormal increase in immunoglobulin levels in either serum or cerebrospinal fluid (13). Ferrari et al (18) reported elevated $\operatorname{lgG}$, IgM, and IgA antibody-titers in the serum of autistic patients, although significance was only reached for IgG titers. In contrast, in the study of Gupta et al (19), $20 \%$ of children with autism had a deficiency of $\operatorname{lgA}$ and $8 \%$ lacked it completely, and $20 \%$ had an IgG subclass deficiency. Serum levels of IgM and IgE were increased in $56 \%$ of patients, and high levels of IgG1 subclass were found in only 2 patients. We found significantly higher concentration of $\lg A$, $\lg G 1$, IgG2, and IgG4. In 8 of 35 persons with autism (23\%)

Table 2. Age and plasma concentration of immunoglobulins (mean \pm standard deviation) in male and female persons with autism and their healthy brothers or sisters

\begin{tabular}{|c|c|c|c|c|c|c|}
\hline \multirow[b]{2}{*}{$\underline{\text { Parameters }}$} & \multicolumn{6}{|c|}{ Findings in } \\
\hline & healthy brothers $(n=7)$ & autistic males $(n=24)$ & $p$ & healthy sisters $(n=14)$ & autistic females $(n=11)$ & $p^{*}$ \\
\hline Age (year) & $14.1 \pm 3.4$ & $9.9 \pm 5.8$ & 0.031 & $12.8 \pm 7.4$ & $9.8 \pm 6.5$ & 0.305 \\
\hline$\underset{\text { IgA }}{\text { Immunoglobulins }(\mathrm{g} / \mathrm{L}) \text { : }}$ & $162+0.32$ & $147+037$ & 0338 & $147+077$ & $186+105$ & \\
\hline $\lg M$ & $0.92 \pm 0.24$ & $1.34 \pm 1.02$ & 0.293 & $1.36 \pm 0.27$ & $\begin{array}{l}1.06 \pm 1.05 \\
1.41 \pm 0.45\end{array}$ & 0.737 \\
\hline $\lg G$ & $10.61 \pm 2.28$ & $12.68 \pm 3.69$ & 0.171 & $11.07 \pm 2.07$ & $14.28 \pm 3.66$ & 0.012 \\
\hline IgG1 & $5.24 \pm 4.13$ & $8.06 \pm 2.40$ & 0.027 & $6.37 \pm 3.38$ & $9.41 \pm 2.20$ & 0.021 \\
\hline IgG2 & $2.40 \pm 1.26$ & $2.36 \pm 0.94$ & 0.927 & $2.51 \pm 1.23$ & $2.61 \pm 1.46$ & 0.857 \\
\hline IgG3 & $0.41 \pm 0.16$ & $0.45 \pm 0.19$ & 0.616 & $0.48 \pm 0.21$ & $0.46 \pm 0.24$ & 0.830 \\
\hline $\operatorname{lgG} 4$ & $0.66 \pm 0.43$ & $0.76 \pm 0.44$ & 0.597 & $0.35 \pm 0.16$ & $0.52 \pm 0.35$ & 0.122 \\
\hline
\end{tabular}


we found lower levels of IgA compared to the normal values (data are not shown). Wareen et al (12) reported that $20 \%$ of individuals with autism had low serum IgA. Thus, IgA deficiency is more common in autism than in normal white population.

Low levels of IgG, IgA, and IgM and subfractions of IgG were found by Zimmerman et al (6). They reported several autistic patients, positive for antinuclear antibodies, characteristic for autoimmune disorders like lupus or rheumatoid arthritis (6). Croonenberghs et al (7), found increased serum concentrations of $\operatorname{lgG}$, IgG2, and IgG4. They reported positive correlations between social problems and total serum proteins and serum gamma globulins, as well as between the withdrawal of the symptoms and total serum proteins and serum albumin and IgG.

Intravenous immunoglobulin infusions have been tested as immunotherapy for autism (11), although the preliminary results are inconclusive and there is a risk of potentially fatal transmission of blood-borne pathogens. In a double-blind and placebocontrolled crossover study immunoglobulins and identical placebo injections were administered once in a dose of $0.4 \mathrm{~g} / \mathrm{kg}$ strength (20). None of the clinician ratings $(A B C$ factors and the symptom checklist scores) showed significant differences between placebo and immunoglobulins (20). Given a positive response rate of only $10 \%$ (13), along with the high costs of immunoglobulin treatments, the use of intravenous immunoglobulin to treat autistic children should be undertaken only with great caution.

Various results of specific immunoglobulines are published in the literature. IgG anti-brain autoantibodies were present in $27 \%$ of the sera from children with autism spectrum disorders, compared with $2 \%$ from healthy children. IgM autoantibodies were present in $36 \%$ of the sera from children with autism spectrum disorders compared with $0 \%$ of control sera $(14$ 21). Measles-IgG and HHV-6-IgG titers were moderately higher in autistic children but they did not significantly differ from normal controls. Singh et al (15), 1997 found a significant increase in incidence of neuron-axon filament protein (anti-NAFP) and anti-glial fibrillary acidic protein (anti-GFAP) in autistic subjects. Clinically, these autoantibodies may be related to autoimmune pathology in autism. Serum antibodies binding to rodent Purkinije cells and other neurons were detected in a mother of 3 children (the first normal, the second with autism, and the third with a severe specific language disorder), which supports the role of maternal antibodies in some forms of neurodevelopmental disorder (22).

Increased serum concentrations of IgGs in autism may point towards an underlying autoimmune disorder and/or an enhanced susceptibility to infections resulting in chronic viral infections, whereas the IgG subclass skewing may reflect different cytokinedependent influences on autoimmune B cells and their products. The reported IgG binding to the epithelial cell surface, lymphocyte infiltration, and increased crypt cell proliferation in the small bowel of children with autism, raised the possibility of autoimmunity in severe autism $(23,24)$. More precise results could be found if specific antibodies to invadors and autoantibodies to different CNS proteins are investigated in children with autism.

\section{Acknowledgement}

This work was part of the project "Serum Immunoglobulins and Specific Food Allergens in the Persons with Autism in Republic of Macedonia" sponsored by the Ministry of Sciences of Republic of Macedonia (Grant No. 40221400/0). Special thanks go to Olivija Efinska-Mladenovska and Elena Zharieva for their valuable help, and to Dr Aleksandar Petlichkovski for critical reading of the manuscript.

\section{References}

1 American Psychiatric Association. Diagnostic and statistical manual of mental disorders. 4th ed. Waschington (DC): Amer Psychiatric Pub; 1994.

2 Korvatska E, Van de Water J, Anders TF, Gershwin ME. Genetic and immunologic considerations in autism. Neurobiol Dis. 2002;9:107-25.

3 Vojdani A, Pangborn JB, Vojdani E, Cooper EL. Infections, toxic chemicals and dietary peptides binding to lymphocyte receptors and tissue enzymes are major instigators of autoimmunity in autism. Int J Immunopathol Pharmacol. 2003;16:189-99.

4 Warren RP, Singh VK, Averett RE, Odell JD, Maciulis A, Burger RA, et al. Immunogenetic studies in autism and related disorders. Mol Chem Neuropathol. 1996;28: 77-81.

5 Fiumara A, Sciotto A, Barone R, D'Asero G, Munda S, Parano E, et al. Peripheral lymphocyte subsets and other immune aspects in Rett syndrome. Pediatr Neurol. 1999;21:619-21.

6 Zimmerman AW, Potter NT, Stakkestad A, Frye VH. Serum immunoglobulins and autoimmune profiles in children with autism (Abstract). Ann Neurol. 1995;38:528.

7 Croonenberghs J, Wauters A, Devreese K, Verkerk R, Scharpe S, Bosmans E, et al. Increased serum albumin, gamma globulin, immunoglobulin IgG, and IgG2 and IgG4 in autism. Psychol Med. 2002;32:1457-63.

8 Jyonouchi $\mathrm{H}$, Sun S, Itokazu N. Innate immunity associated with inflammatory responses and cytokine production against common dietary proteins in patients with autism spectrum disorder. Neuropsychobiology. 2002; 46:76-84.

9 Singh VK, Warren R, Averett R, Ghaziuddin M. Circulating autoantibodies to neuronal and glial filament proteins in autism. Pediatr Neurol. 1997; 17:88-90.

10 Warren RP, Yonk J, Burger RW, Odell D, Warren WL. DR-positive T cells in autism: association with decreased plasma levels of the complement C4B protein. Neuropsychobiology. 1995;31:53-7.

11 Gupta S. Immunological treatments for autism. J Autism Dev Disord. 2000;30:475-9.

12 Warren RP, Margaretten NC, Pace NC, Foster A. Immune abnormalities in patients with autism. J Autism Dev Disord. 1986;16:189-97.

13 Plioplys AV, Greaves A, Yoshida W. Anti-CNS antibodies in childhood neurologic diseases. Neuropediatrics. 1989;20:93-102.

14 Connolly AM, Chez MG, Pestronk A, Arnold ST, Mehta $S$, Deuel RK. Serum autoantibodies to brain in Landau-Kleffner variant, autism, and other neurologic disorders. J Pediatr. 1999;134:607-13.

15 Singh VK, Lin SX, Yang VC. Serological association of measles virus and human herpesvirus- 6 with brain 
autoantibodies in autism. Clin Immunol Immunopathol. 1998;89:105-8.

16 Zimmerman AW. Commentary: immunological treatments for autism: in search of reasons for promising approaches. J Autism Dev Disord. 2000;30:481-4.

17 World Health Organisation. International classification of diseases and related health problems. 10th Revision. Geneva: WHO; 1992.

18 Ferrari P, Marescot MR, Moulias R, Bursztejn C, Deville Chabrolle A, et al. Immune status in infantile autism. Correlation between the immune status, autistic symptoms and levels of serotonin [in French]. Encephale. 1988; 14:339-44.

19 Gupta S, Aggarwal S, Heads C. Dysregulated immune system in children with autism: beneficial effects of intravenous immune globulin on autistic characteristics. J Autism Dev Disord. 1996;26:439-52.

20 Niederhofer H, Staffen W, Mair A. Immunoglobulins as an alternative strategy of psychopharmacological treatment of children with autistic disorder. Neuropsychopharmacology. 2003;28:1014-5.

21 Vojdani A, Campbell AW, Anyanwu E, Kashanian A, Bock K, Vojdani E. Antibodies to neuron-specific antigens in children with autism: possible cross-reaction with encephalitogenic proteins from milk, Chlamydia pneumoniae and Streptococcus group A. J Neuroimmunol. 2002;129:168-77.

22 Dalton P, Deacon R, Blamire A, Pike M, McKinlay I, Stein J, et al. Maternal neuronal antibodies associated with autism and a language disorder. Ann Neurol. 2003; 53:533-7.

23 Senior K. Possible autoimmune enteropathy found in autistic children. Lancet. 2002;359:1674.

24 Licinio J, Alvarado I, Wong ML. Autoimmunity in autism. Mol Psychiatry. 2002;7:329.

Received: November 10, 2003

Accepted: October 4, 2004

\section{Correspondence to:}

Mirko Spiroski

Institute of Immunobiology and Human Genetics

Medical Faculty

PO Box 60

1109 Skopje, Republic of Macedonia

mspiroski@yahoo.com 